\title{
On Reform of Human Rights Education in Mainland China
}

\author{
Taixia Shen \\ Law School/Intellectual Property School \\ Jinan University \\ Guangzhou, China \\ Sunbird726@hotmail.com
}

\begin{abstract}
Human right education in mainland China developed quickly in recent years. The problems became visible in the progress of its development. The development ideas and methods should be adjusted. A reform of human rights education in mainland China is necessary for its further development. Human rights education should be launched for masses, should be further popularized; human rights education resources should be delivered evenly, get to a balanced development; the teaching methods and contents should be improved; both the quantity and quality of human rights teachers should be increased; The government and society should establish special funds for promoting human rights education.
\end{abstract}

Keywords-reform; human rights education; mainland China; development

\section{INTRODUCTION}

With the development of democracy and social progress in mainland China, "human rights education developed quickly in recent years. Human rights courses were opened in some colleges and universities in the 1990s. The research and training centers of human rights are established gradually all over the country."[1] In 2004, the term of "human right protection" was written into the Constitution of mainland China, "National Human Rights Action Plans" stressed that the government would promote human rights education. Human rights education has gained recognition from the government and civil society, and it is entering the peak of its development in history. Meanwhile Human rights education of mainland China has its main problems during its development. This paper firstly analyzes its main problems and then argues that a reform needs to be carried out for solving these problems, the ideas and measures of reform will subsequently be given. Based on the analyses of each part, it finally makes a conclusion that Human rights education in mainland China should get to a sustainable development through a reform.

\section{PRoBlems Of Human Rights EdUCATION IN MAINLAND CHINA}

Though the human rights education of mainland China has great achievements, there are still some difficulties need to be overcome for its further development. This part summarizes its main problems as follows.

\section{A. Popularization of Human Rights Education at the Low Level}

Be different from other countries and areas, human rights education in mainland China firstly launched at university and colleges, rather than in daily life, at primary and secondary school. Relying on the rich intellectual and academic resources, many top colleges and universities set up human rights courses quickly. These courses are mainly given by the teachers from law school. Moreover, many universities and colleges established human rights research institutions or training bases to promote human rights research and education.

Besides, human rights education is consistently carried out among public servants, many human rights research centers and training bases provide human rights law courses for the government employees especially for the people working in public security agencies, procuratorates, courts, prisons, urban management organs, and administrative law enforcement organs. For instance, "from 2006 to 2010, Human rights research center and training base of Guangzhou University carried out human rights law courses for the public servants from criminal judicial system of Guangdong and other areas.” [2]

It can be easily found that human rights education in mainland China was firstly carried out for the students at university and college, it was then carried out for the professional training for the public servants, and then it will be launched at primary and secondary school. Till now, there are no special human rights courses opened for the students at primary and secondary school, no human rights education in daily life. In all, the popularization of human rights education remains at the low level in mainland China.

\section{B. Unbalanced Development}

Human right education in mainland China developed quickly but not balanced. Firstly, human rights courses are mainly launched at university while there are still no special human rights courses for the students at primary and secondary school, the moral education are carried out instead. In other words, the development of human rights education at primary and secondary school lags behind its development at university. Secondly, the top universities and law schools set up human rights courses while there is still a lack of human rights courses in many ordinary universities and law schools, which means there is a gap between the top universities and ordinary 
universities in the development of human rights education. Thirdly, Human rights education developed quickly in the developed areas while it was restricted in the less developed areas. For example, there are at least 3 tops human rights research centers and training bases in Peking, there are Renmin University of China Human Rights Research Center, Human Rights and Humanitarian Law Research Center Peking University Law School and the China University of Political Science and Human Rights Research Institute, while there is none in some cities of west China. The resources of human rights education are unevenly distributed in mainland China. Human rights education in the minority areas is less developed. The status of human rights education is relatively low, there is lack of realization of its importance, the course construction is not reasonable, "many universities of the minority areas still look on human rights courses as dispensable.”[3] The development differences in the developed and less developed areas are widening.

\section{More Theory but Less Practice in Human Rights Education}

Giving human rights courses is the main mode of human rights education in mainland China. In the course of human rights, the teachers give more theory, less practice; they prefer to the international human rights theory and practice to the domestic human rights theory and practice as the mechanisms of protection of human rights in mainland China are developing; the teachers use some foreign human rights cases rather than the Chinese cases as there are not enough jurisprudence in mainland China. Though the students have interests in getting human rights knowledge, their abilities for solving the problems in practice need to be improved. Both the Human rights knowledge and awareness should be emphasized in human rights education while the human rights practice is still underemphasized. Giving lectures, text reading, case study, standardized tests are the main teaching methods of Human rights courses, not many schools carry out legal aid at grassroots level, set up legal clinics for practicing human rights knowledge. In brief, human rights education in mainland China is biased towards theory rather than practice. Both the teaching ideas and methods should be reformed.

\section{Limited Funds for Human Rights Education}

The funds of human rights teaching is relatively low. Although the National Planning Office of Philosophy and Social Science (NPOPSS), the Ministry of Education of the People's Republic of China (MOEPRC) and the Ministry of Justice of the People's Republic of China (MOJPRC) have set up lots of funds for social science research, the funds for research on human rights are limited. Besides, most of these funds are mainly for the academic research on human rights, while ignore for human rights education. It is embarrassing that till now a lot of projects on human rights education at university rely on the international funds, the unstable source of funds will inevitably restrict the sustainability of human rights education at university. The social donation is also limited in this field. Now the MOEPRC allocate the national funds for the national human rights education and training bases, while the other human rights teaching organizations cannot get this kind of funds; the universities often allocate limited funds to its human rights research centers and training bases. In a word, there are no special funds for human rights education in mainland China.

\section{E. Shortage of Human Rights Teachers at School}

There is a lack of human rights teachers in some colleges and universities, especially for primary and secondary schools. Sometimes the leaders of universities want to open human rights courses while it is impossible to carry out as there is no right person who is equipped for giving human rights courses. "In some universities, the teachers of human rights courses are from the relative majors such as constitutional law, theory of law or criminal law, there are no special human right law teachers."[4] Those years more and more young scholars join in the team of human rights teaching, however, the number of human rights teachers is smaller comparing with the number of other traditional law subjects. Most of the human rights teachers are not well equipped with the international human rights knowledge and practice. There are no special human rights teachers, no special human rights textbooks for the students at primary and secondary schools.

\section{REFORM MEASURES OF HUMAN RightS EDUCATION IN MAINLAND CHINA}

Analyzing the problems of human rights education in mainland China, this part argues that the ideas and methods of development of human rights education in mainland China should be changed. It tries to give the following measures to solve the existing problems, to promote the sustainable development of human rights education in mainland China.

\section{A. Popularizing Human Rights Education in Mainland China}

Human rights should be one of the main values of the society in mainland China, human rights issue and education should be no longer sensitive. Promoting human rights education is the duty of the governments, it is necessary to attach great importance of human rights education by the governments, the leaders of the universities as well as the primary and secondary school. First, human rights courses must be opened as a compulsory course or optional course both for the students from law school and from other schools in the whole university. For this purpose, the MOEPRC can list the human rights law into the compulsory courses for the students at law school, as well as list human right law into the examination subjects of the National Judicial Examination. Second, human rights education should not stay at university, it should be promoted preferentially at primary and secondary school in the near future, should be carried out in everyday life, and it should be universal education for every citizen. Specifically, human rights courses should be set up at primary and secondary school, teachers can give human rights lessons by using the suitable textbooks or materials, and teaching methods.

Besides of the normal schools, the society and the parents also have duties to deliver and promote human rights education in everyday life. Let "human rights" go to and live in everyday life of the citizens. That is the real popularization of human rights education. 


\section{B. Heading to a Balanced Development}

Human rights education in mainland China should overcome the obstacles of balanced development, solve the existing problems. First, the development speed of human rights education at primary and secondary school should be picked up, the government should increase the investments for that, and scholars should do the preparing work such as editing the suitable textbooks or reference books for the pupils and middle school students. Second, the gap of human rights education development between the top universities and ordinary ones should be narrowed. The MOEPRC should encourage human rights education develop in every university, the central and local governments and the universities should invest for development of human rights education, should help the schools which have no such education to set up human rights courses, undeveloped schools should get more support for promoting human rights education. Third, the governments should increase the investment and funds for the development of human rights education in the undeveloped areas. The local governments should open their minds to promote human rights in the undeveloped areas. The developed areas and schools should help the undeveloped areas and schools to promote human rights education.

\section{Improving the Teaching Methods of Human Rights Education}

It is possible to improve the teaching methods of human rights courses. Teachers should not limit to give the boring lectures, the translation of international human rights documents, they should give some practice and jurisprudence, the aims of teaching human rights law is not only to let the students get knowledge, but also to let them know how to protect and improve their human rights, to enhance their awareness of human rights. It is useful to play an active initiative of students, to discover their own reality in the field of human rights. Human right is not on the book, but in action. More effective teaching methods can enhance the interests and enthusiasms of students to accept human rights courses. In the area of human rights education, "teachers should use the participation method, interactive method and research method to help the students for acquiring human rights knowledge.”[5] The grass-roots level investigation should be encouraged, the legal clinics for human rights should be opened for practicing human rights knowledge, and the community service should be launched. Human rights research centers and training bases should do some legal aids for the vulnerable groups and should disseminate human rights knowledge for them. Sometimes, human rights education should be launched with the human rights programs and practice of governments, it should do service for the society.

\section{Establishing Special Funds for Human Rights Education}

The government should increase the funds for human rights research and education, particularly for human rights education at university, at primary and secondary school. The NPOPSS, the MOEPRC and the MOJPRC should enlarge the funds for human rights research, the MOEPRC and local governments should set up special funds for human rights teaching. Till now the MOEPRC have established 8 national human rights research centers and training bases, given huge funds for the human rights research and education. Those years, the China Society for Human Rights Studies do great contribution to the human rights research and human rights education, it set up special funds for human rights research and have already held 7 sessions of national conferences for exchanging the experiences of human rights education and research. In future, the funds for human rights education should be enlarged and not only for the national human rights research centers and training bases, they should be for every school or organization for launching human rights education. The government has responsibilities to set up funds for human rights teaching in the universities, primary and secondary schools which have not carried out human rights education. The governments should set up special funds for the development of human rights education in the minorities' areas. The society also has the responsibility to promote and improve human rights education, the funds from the civil society or enterprises for promoting human rights education should be encouraged.

\section{E. Increasing the Quantity and Quality of Human Rights Teachers}

Facing the problem of lack of human rights teachers, the governments and universities should increase the quantity of human rights teachers, they can introduce mature people in the field of human rights education, as well as cultivate their own talents.

Human rights teachers should have the professional knowledge and skills in the field of human rights education. It is clear that human rights teachers should love to teach human rights courses, spend enough time and efforts in human rights teaching, then should have a solid theoretical foundation of human rights. Teachers should have received appropriate training in human rights law. With the internationalization of human rights education, the human rights teachers should know the international human rights law, should acquire English or other foreign languages. Enhancing the communication and cooperation with the international academic or educational institutions is also useful for the improvement of human rights teachers of mainland China. The governments and the schools have the responsibilities to train their human rights teachers regularly, in the following years, the governments, universities, primary and secondary schools should strengthen training teachers to carry out human rights education at primary and secondary school. The human rights education knowledge and methods for the students at primary and secondary school should be different from they are at university. Furthermore, the governments should establish the training programs for the teachers from the schools in the undeveloped areas, for example, the schools in west China.

\section{CONCLUSION}

Human rights and human rights education in mainland China have developed since the Chinese reform and open, and grew quickly those years, especially at university. There is no denying that Chinese human rights education has great achievements.

However, many difficulties and obstacles are still ahead. Some leaders of governments and schools still think human rights courses are sensitive, they don't make a point of 
launching human rights courses. Low coverage, unbalanced development, limited funds for human rights teaching, more theory less practice in the course of human rights and a lack of qualified teachers are the main problems of human rights education in mainland China. It needs a reform to solve these problems for a sustainable development. Thinking and discussing the reform and its specific measures are necessary and important.

Based on the main problems analyzed, this paper argues that enhancing awareness of the whole society to respect and protect human rights, attaching great importance to human rights and human rights education, popularizing human rights education at school, in the society and everyday life, heading for a balanced development, allocating human rights education resources evenly, reforming the teaching methods and contents of human rights courses, establishing special funds for human rights education, increasing the quantity and quality of human rights teachers are the effective measures.

It is clear that the development of Chinese human rights education in mainland China is at the crucial moment. Respect of human rights is one of the main topics of the Fourth Plenary Session of the 18th Central Committee of the Communist Party of China, which will promote the further development of human rights education in mainland China. With the supportive policy of governments, the effective reform measures, the future of human rights education in mainland China is full of hope.

\section{ACKNOWLEDGMENT}

The research is the result of the Project entitled "Intellectual Property in Human Rights Perspective” (No. 13YJC820069) funded by the Ministry of Education of the People's Republic of China, is financed by the "Central Universities Fundamental Research Fund”.

\section{REFERENCES}

[1] Guangshun Fang, Lei Zhang. "Popularization of human rights education of China within 10 years: from 2001 to 2011,” Human rights, No.6, pp.40-44,2012.

[2] Shiping Liu. "the History and the Future of the Human Rights Education at university of China,” Human rights, No.5, pp.30-32,2013.

[3] Zhiyuan Peng. "A Study of Human Rights Education in the Universities of the Minority Areas,” Journal of Inner Mongolia Finance and Economics College, Vol.10, No.5,pp.19-24,2012.

[4] Youwu Chen. "Problems of Human Rights Education in China's Universities and Its Solution,” Journal of Guangzhou University- Social Science Edition,Vol. 9, pp.25-28,2010.

[5] Shiping Liu, Yuyi Zhou. “ On the National human rights action plan and the enforcement of human rights education at university in mainland China,” Human Social Science, No.3, pp.215-219,2014. 